\title{
A Review of Social Studies Course Books Regarding Digital
}

\section{Literacy and Media Literacy}

\author{
Hüseyin Erol $^{1}$ \\ ${ }^{1}$ Place of duty: Adiyaman University, Faculty of Education, Department of Social Studies, Turkey \\ Correspondence: Hüseyin EROL, Place of duty: Adıyaman University, Faculty of Education, Department of Social \\ Studies, Turkey. Orcid: 0000-0002-4707- 5152
}

Received: January 17, 2021

Accepted: April 27, 2021

Online Published: April 30, 2021

doi:10.5430/ijhe.v10n5p101

URL: https://doi.org/10.5430/ijhe.v10n5p101

\begin{abstract}
This study investigated the extent to which digital literacy and media literacy among the 21st century skills are included in the social studies curriculum of the 4th, 5th, 6th and 7th grades in Turkey. Among qualitative research methods, the document analysis was used in the study. Since the data were collected from printed and digital materials, this method was believed to be appropriate. The study is limited to social studies course books that re taught to the 4th, 5th, 6th and 7th grade students in Adiyaman province of Turkey in the 2020-2021 academic year. The study found that among the skills included in the social studies curriculum, digital literacy and media literacy skills are included. Four learning outcomes in the curriculum (no: 5.4.1, 5.4.2, 5.4.3. and 7.5.6.) are associated with digital literacy and 3 learning outcomes (no: 5.4.2, 6.7.4, 7.1.3.) are associated with media literacy. Among all learning outcomes in the curriculum (127 learning outcomes), the digital literacy and media literacy are included at a rate of $5.51 \%$. The contents on digital literacy and media literacy were not distributed balancedly in the social studies course books and the contents that could be associated with digital literacy and media literacy in the social studies course books of the 5 th and 7 th grades were included. Of the contents in the 5th and 7th grade social studies course books, $6.6 \%$ were related to digital literacy and $6.24 \%$ were related to media literacy. However, there were no content in the 4th and 6th grade social studies course books that could be associated with digital literacy or media literacy. On the other hand, the contents related to digital literacy and media literacy in the social studies course books were consistent with the learning outcomes in the curriculum. The number of learning outcomes regarding these two literacy types can be increased in the curriculum. The number of contents about digital literacy and media literacy can be increased in the social studies course books to be published. The contents on digital literacy and media literacy at every class level (4th, 5 th, 6 th and 7 th grade) provided with social studies course can be distributed equally.
\end{abstract}

Keywords: digital literacy, media literacy, social studies, course book, learning outcomes

\section{Introduction}

The main factor that has facilitated personal and social life since the existence of human has become knowledge. The fund of knowledge passed down from generation to generation has played an important role in the socialization period of human, establishment of the first settlements and acquisition of cohabiting culture. The information transfer that begins in the family continues in a more formal way in school within the scope of certain rules. The dominating understanding in education period may affect the way of using knowledge. While it is deemed sufficient to learn and store knowledge in some of these insights, the practical use of knowledge acquired in different education perspectives is deemed a basic criterion. The century we live in is the time period when knowledge is produced and spread most (Kalkınma Bakanlığı, 2013). The 21st century which is also called information age requires people to have some basic skills so that they can not only store information, but choose, analyze and evaluate it, but also use the information they have obtained in their daily life and turn it into a product. The majorly stems from life becoming international and multicultural and interdependence of people. Therefore, new skills are necessary to be successful in working life (Suto, 2013). Those skills that allow individuals to work in collaboration and coordination and require high-level thinking skills are called as 21 st century skills. These skills have been subject to classification in recent years by many institutions. These institutions include Asia Society Partnership for Global Learning (ASIA Society), Assessment and Teaching of 21st Century Skills (ATCS), European Union (EU), International Society for Technology in Education (ISTE), North Central Regional Educational Laboratory (NCREL), Organization for Economic Co-operation and Published by Sciedu Press 
Development (OECD) and Partnership for 21st Century Skills (P21) (Benek, 2019). The main objective of these institutions in classifying skills is to determine the criteria on which the generations with 21 st century skills will be trained. It is undeniable that the structure controlling the change and individuals with the compulsory 21 st century skills who have global values such as justice, morality, quality, freedom, prosperity, order, peace, reconciliation and tolerance that change with the nature of information. The classification made by the P21 platform among the institutions that classify the 21 st century skills is generally accepted in the education world.

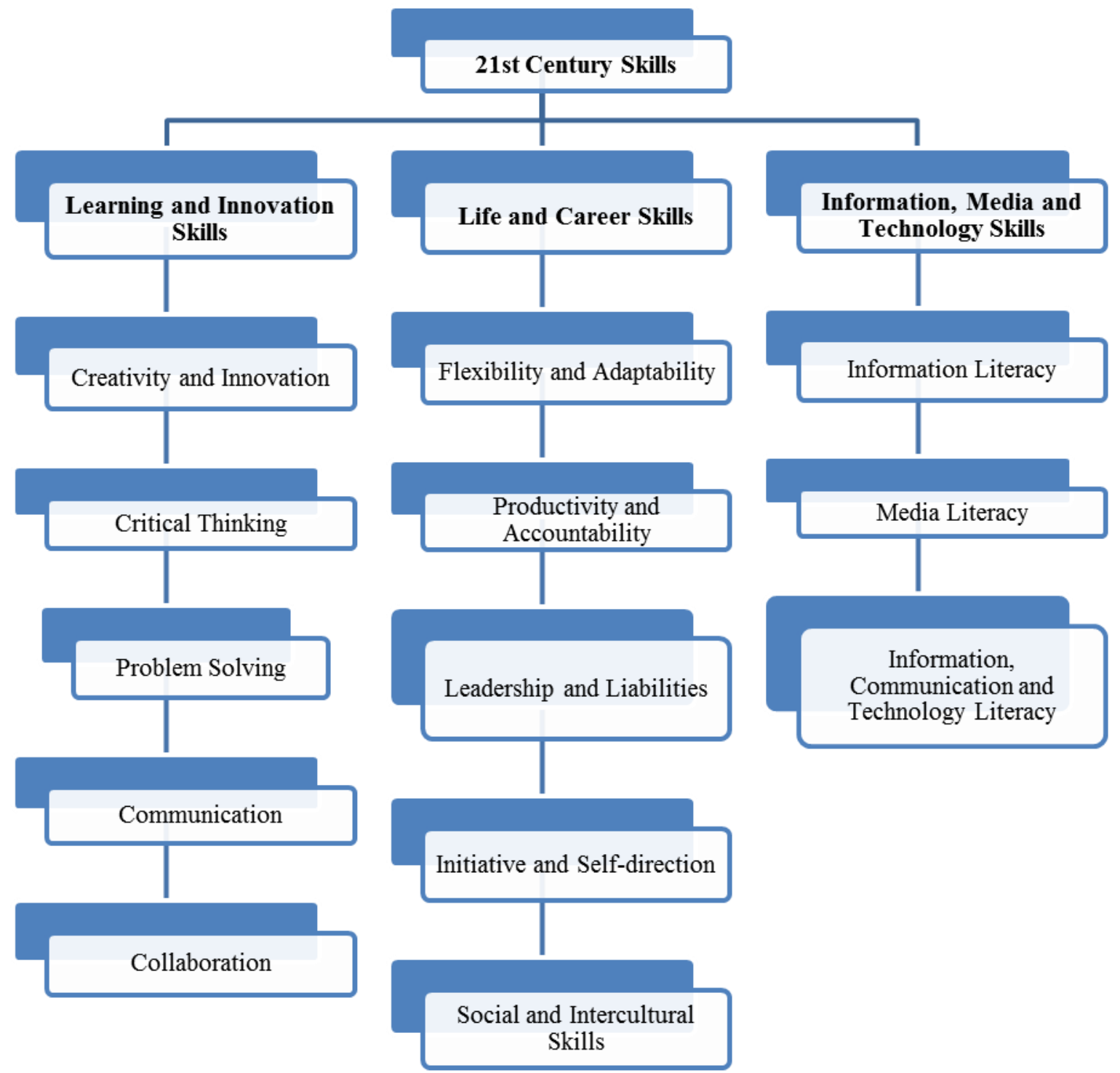

Figure 1. P21 Classification of the 21st Century Skills

The classification made by the P21 indicates that the 21 st century skills consist of three main components that are learning and innovation skills, life and career skills, and information, media and technology skills. These components are each categorized under subheadings. The skills classified by the P21 have taken up in basic approaches of education programs in recent years.

Information literacy and media literacy skills that constitute the subskills of information, media and technology skills, among these skills, and include many types of literacy have come to the fore directly concerning all segments of society today. Today, developments in information and communication technology have led to radical changes in students' knowledge acquisition and facilities. Thanks to such improvements, the students have had the chance to communicate in written, visual, auditory forms using certain tools. It is possible to see its traces in daily life. In particular, with the widespread use of the internet, students have to learn and adapt the skills needed for directing, evaluating and using information (Treske, 2011). Individuals of information age are intertwined with environments 
rich in technology and media. They can manage multiple activities at the same time as required by the age, use the Internet to watch TV, make research while speaking on the phone and use time sophisticatedly. This majorly regulates the concepts of communication, knowledge management, learning, personal and social values of the rising generation. A similar case applies to adults who use information and communication technologies either for personal or professional needs (Pedro, 2006). Today, easy and unlimited access to information, rapid change in technological tools and the potential of changing life at the same rate have made it obligatory for individuals to use, analyze and evaluate the information, media and technology actively in the most accurate way so that they can be individuals of the 21 st century $(\mathrm{P} 21,2015)$.

Digital literacy and media literacy have come to the fore with digitalization of communication. It has many definitions besides having the same point of view with digital literacy fundamentally. Turkish Language Society defines digital literacy as display of numerical data on a screen electronically (http//sozluk.gov.tr, 2020). Accessing appropriate and secure content and communicating through media are defined as digital literacy by understanding information from different sources using a computer, knowing how to use new technologies, creative thinking, sorting, evaluating, criticizing information and creating digital contents (Hague and Payton, 2010; Gilster, 1997). Correct use of different technologies in this literacy is defined as awareness, attitude and ability to access the correct information, produce and share information, benefit from technology in learning-teaching process, and manage and integrate achievements (Hamutoğlu, Güngören, Uyanık and Erdoğan, 2017; Martin, 2006). Considering the definitions, the minimal technical skills that users should have to use technology effectively and fulfill their main tasks are defined as digital literacy (Buckingham, 2010). Digital literacy is divided into five categories including photo-visual literacy, reproduction literacy, navigation literacy, information literacy and socio-emotional literacy (Eshet-Alkalai, 2004). Media literacy that is deemed sub-discipline of digital literacy was first discussed in 1960s by UNESCO by defining the critical role of the media in social development at that time and by demonstrating its sensitivity to the idea of creating and maintaining communication spaces (Berber, 2019). Media literacy is literally defined as a viewpoint that enables people to interpret messages from the media and the process of constructing a meaning map that comes out of individuals' relationships between media texts and consumption practices (Potter, 1998; Binark and Bek, 2007). This literacy skill can also be defined as the ability to easily access to, analyze and evaluate images, words and sounds in daily life and the integration of thinking skills with reading, watching, speaking and listening skills that can be practiced through the media (Europe's Information Society, 2007; Carmen, 1999). Individuals reach a certain level of awareness thanks to media literacy and have the opportunity to make contribution to themselves being active, thinking and questioning besides their environment (Gülmüş, 2020). They can acquire top-level thinking skills and so, understand the codes of the world better. They can have active evaluation on them and make personal judgments by having the ability to criticize (Aksu, 2019). Media literacy stands for being an important acquisition process for all nations to survive as mentally and physically healthy societies as of a near period of time (Alimc1, 2019; Som and Kurt, 2012). Families can use digital media as a tool to rush to their business in daily life, to provide a safe environment for the child, to help in education of the child or to entertain the child (Tomopoulos et al, 2010). The studies conducted with all age groups found that children watch television for four hours a day on average and they decide themselves (82\%) about watching television. Children can choose the programs they wish and sometimes they can watch television as long as they want (Bakan, 2010). This is because technological developments and the changes in daily media usage in the current age have mobilized all information and experiences. Information, news, entertainment and experiences constantly flow between media tools and multiple borders. Young individuals can learn more from the tools of the digital world than they learn from books and their teachers at school. The media has become a major control power on children and young people in particular through its impact, scope and direction (İnal, 2009; Kurtulmuş, 2014; Ulusoy, 2018; Gençer, 2018). Thus, the students should acquire the skills of receiving, analyzing and interpreting messages obtained from different media and Internet tools from a critical point of view. These should be included in the related course materials regarding how correct information can be accessed in information mass within digital resources. The students should be directed in this sense (https://medyaokuryazarligi.gov.tr, 2021). Media literacy is taught as an elective course in secondary schools in Turkey to students who are expected to analyze and evaluate in a critical perspective by understanding text and audiovisual media messages correctly, and accessing and understanding messages from other digital media, such as social networks, new media, and video games. Being an elective course only allows demanding students to access the contents of the course. Also, some of the content of media literacy and therefore digital literacy is included in the social studies. Thus, social studies education which shows the students many dimensions of events and develops their decision-making skills, imagination and creativity skills is very important in terms of media and media education (Kurtulmuş, 2014). 
In the literature review, the studies on digital literacy and media literacy have been detected to increase in recent years. In particular, studies on digital literacy (Cebeci, 2020; Altıner, 2019; Kara, 2021; Korkmaz, 2020; Yaman, 2019; Gürtekin, 2019; Özoğlu, 2019; Yaşar, 2019; Boyacı, 2019; Arslan, 2019; Bozyel, 2019; Kozan, 2018; Altun, 2019) mainly focused on determining the digital literacy skills of teacher candidates, besides the studies conducted on university students from different departments (Dayanıkl1, 2019). The studies on the relationship of social studies and media literacy (Altun, 2010; Dolanbay, 2018) were found to be very few. No study has been found where social studies curriculum and social studies textbooks were examined in the context of digital literacy and media literacy. The students should acquire the skills of receiving, analyzing and interpreting messages obtained from different media and Internet tools from a critical point of view. Correct information in information mass in digital resources should be accessed and included in course materials.

This study seeks into determine the extent to which social studies curriculum that was updated in 2018 and course books include digital literacy and media literacy skills that are covered in education programs. The following questions seek answers for the study to achieve its goal:

a) To what extent are digital literacy and media literacy skills included in the 2018 curriculum of social studies?

b) To what extent are digital literacy and media literacy skills included in the 4th grade social studies course book?

c) To what extent are digital literacy and media literacy skills included in the 5th grade social studies course book?

d) To what extent are digital literacy and media literacy skills included in the 6th grade social studies course book?

e) To what extent are digital literacy and media literacy skills included in the 7th grade social studies course book?

\section{Method}

This study used qualitative research model. In qualitative research, the data are collected through observation, interview and documents (Berg and Lune, 2015; Merriam, 2009). The data of this study were collected using document analysis. The document analysis was believed to be the appropriate method since the social studies curriculum in practice and the course books were examined in line with the aim of the study. Document analysis is qualitative method that is used to analyze the content of written documents meticulously and systematically (Wach, 2013). The document review includes analysis of written materials that comprise information about the targeted case or cases for investigation (Yıldırım and Şimşek, 2016). This study is limited to the social studies curriculum that was updated and put into effect in 2018, and the social studies course books of the 4th, 5th, 6th and 7th grades in Adiyaman in the 2020-2021 academic year.

\subsection{Data Collection}

In this study, social studies books taught in secondary schools in the province of Adiyaman located in the Republic of Turkey were investigated. In collecting the data, the documents to be analyzed were accessed first and the 4th, 5th, 6th and 7th grade social studies course books as well as 2018 curriculum of social studies were obtained. Then, the documents were examined in detail to determine the extent to which social studies curriculum and course books include the digital literacy and media literacy.

\subsection{Validity and Reliability}

To ensure the reliability of the study, 2 social studies teachers and 2 academicians working in the field of social studies were consulted about whether the acquisitions and skills in the social studies curriculum and the contents in social studies textbooks are related to digital literacy and media literacy. The data that were obtained from experts were analyzed. In qualitative research, the validity of the measuring tool is closely related to correct measurement of the case it aims to measure. In this case, the data collected reflect the truth and contribute to the study results (Yildirmm \& Şimşek, 2016).

\subsection{Data Analysis}

In the analysis phase of the documents obtained in line with the study aim, the extent to which digital literacy and media literacy are included in the learning outcomes and skills of the course are shown by examining the curriculum. Afterwards, the contents of the social studies course books, which have been taught to the 4th, 5th, 6th and 7th grades 
in Adiyaman in the 2020-2021 academic year, were examined by the researcher in line with the study aim and the obtained data are given in tables.

\section{Findings and Results}

This section of the study provides findings and interpretations obtained from the research.

Table 1. Learning Outcomes Regarding Digital Literacy in the 2018 Curriculum of Social Studies

\section{Learning Domain $\quad$ Learning Outcomes No. Learning Outcomes}

\section{SB.5.4.1.}

Science, Technology and Society

Production,

Distribution and Consumption

\section{SB.5.4.2.}

SB.5.4.3.

SB.7.5.6.
Discussing the effect of technology use on socialization and society relationships.

Questioning the accuracy and reliability of information obtained from virtual environment.

Obeying the rules while using virtual environment.

Analyzing the changes caused by digital technologies in production, distribution and consumption.

Table 1 shows that the social studies curriculum includes four learning outcomes on digital literacy. These outcomes (three outcomes) are in Science, Technology and Society most. The digital literacy outcomes are included in the 5th and 7 th grades only. There is no digital literacy outcome in the 4th and 6th grades.

Table 2. Learning Outcomes Regarding Media Literacy in the 2018 Curriculum of Social Studies

\begin{tabular}{lll}
\hline Learning Domain & $\begin{array}{l}\text { Learning } \\
\text { Outcomes No. }\end{array}$ & Learning Outcomes \\
\hline $\begin{array}{l}\text { Science, Technology } \\
\text { and Society }\end{array}$ & SB.5.4.2. & $\begin{array}{l}\text { Questioning the accuracy and reliability of information obtained from } \\
\text { virtual environment. }\end{array}$ \\
$\begin{array}{l}\text { Global connections } \\
\text { Individual and Society }\end{array}$ & $\begin{array}{l}\text { SB.6.7.4. } \\
\text { SB.7.1.3. }\end{array}$ & $\begin{array}{l}\text { Questioning the effects of popular culture on our own culture. } \\
\text { Discussing the role of media on social change and interaction. }\end{array}$ \\
\hline
\end{tabular}

Table 2 shows that the social studies curriculum includes three learning outcomes on human rights. These outcomes are included in Science, Technology and Society, Global Connections and Individual and Society learning domains. There is no media literacy outcome in the 4 th grade.

Table 3. Relationship of the Skills in the 2018 Social Studies Curriculum with Digital Literacy and Media Literacy

\begin{tabular}{lcc}
\hline Skills & $\begin{array}{c}\mathbf{2 0 0 5} \\
\text { Social Studies } \\
\text { Curriculum }\end{array}$ & $\begin{array}{c}\mathbf{2 0 1 8} \\
\text { Social Studies } \\
\text { Curriculum }\end{array}$ \\
\hline Research Skills & $\sqrt{ }$ & $\sqrt{ }$ \\
Skills on Perceiving the Changes & $\sqrt{ }$ & $\sqrt{ }$ \\
and Sustainability & $\sqrt{ }$ & $\sqrt{ }$ \\
Critical Thinking Skills & $\sqrt{ }$ & $\sqrt{ }$ \\
Empathic Skills & $\sqrt{ }$ & $\sqrt{ }$ \\
Entrepreneurship Skills & $\sqrt{ }$ & $\sqrt{ }$ \\
Observation Skills & $\sqrt{ }$ & \\
Communication Skills & $\sqrt{ }$ & \\
Decision-making Skills & &
\end{tabular}


Skills on Using Turkish Correctly,

Well and Effectively

Problem Solving Skills

Social Participation Skills

Space Perception Skills

Skills on Perceiving Time and

Chronology

Collaboration Skills*

Skills on Recognizing Stereotype and Prejudice*

Using Evidence Skills*

Position Analysis Skills*

Media Literacy Skills*

Environment Literacy Skills*

Self-control Skills*

Political Literacy Skills*

\section{Digital Literacy Skills*}

Financial Literacy Skills*

Skills on Drawing and Interpreting

Table, Chart and Diagram*

Map Literacy Skills*

Innovative Thinking Skills*

Law Literacy*

Creative Thinking**

Use of Information

Technologies** $\sqrt{ }$

$\sqrt{ }$

$\sqrt{ }$

$\sqrt{ }$

$\sqrt{ }$

$\sqrt{ }$

$\sqrt{ }$

$\sqrt{ }$

$\sqrt{ }$

$\sqrt{ }$

$\sqrt{ }$

$\sqrt{ }$

$\sqrt{ }$

$\sqrt{ }$

$\sqrt{ }$

$\sqrt{ }$

$\sqrt{ }$

$\sqrt{ }$

$\sqrt{ }$

$\sqrt{ }$

* New skills added to the 2018 social studies curriculum

** Skills excluded from the social studies curriculum

Table 3 shows that literacy skills, one of the information literacy types, which was included in the social studies curriculum before (2005) is not included any more. New skills including also digital literacy and media literacy skills in the updated social studies curriculum in 2018 are not included in the curriculum. We can say that these skills could be added in the social studies curriculum thanks to the skills called as 21 st century skills.

Table 4. Contents on Digital Literacy in the 4th Grade Social Studies Course Book

\begin{tabular}{llll}
\hline Learning Domain & Unit & Grade & Subject \\
\hline- & - & - & -
\end{tabular}

According to Table 4, there is no content regarding digital literacy in the 4th grade social studies course book. 
Table 5. Contents on Media Literacy in the 4th Grade Social Studies Course Book

\begin{tabular}{llll}
\hline Learning Domain & Unit & Grade & Subject \\
\hline- & - & - & - \\
\hline
\end{tabular}

According to Table 5, there is no content regarding media literacy in the 4th grade social studies course book.

Table 6. Contents on Digital Literacy in the 5th Grade Social Studies Course Book

\begin{tabular}{llll}
\hline Learning Domain & Unit & Grade & Subject \\
\hline Science, Technology and Society & Science and Technology in Our Lives & 5 & Effect of Technology on the Society \\
\hline
\end{tabular}

Table 6 shows that the 5th grade social studies course book (Ata Publishing) explains the impact of the developments in technology on human relations in the subject of "Effect of Technology on the Society" in the "Science, Technology and Society, Science and Technology in Our Lives" unit. The tools and equipment that facilitate human life are provided and the negative effects of technology on social life are explained in the content. Also, communication through virtual environment is mentioned to weaken face-to-face communication sometimes. The content is supported with complementary visual elements.

Table 7. Contents on Media Literacy in the 5th Grade Social Studies Course Book

\begin{tabular}{l}
\hline Learning Domain \\
Science, Technology and Society Science and Technology in Our Lives \\
\hline According to Table 7, the 5th grade social studies course book (Ata Publishing) states that the general network is an \\
important tool to search for information in the subject of "Library in Our Pockets" in the "Science, Technology and \\
Society, Science and Technology in Our Lives" unit. To access information needed in the period when the general \\
network was not available, the research used to be redacted by use of libraries and reaching out to encyclopedias or \\
different sources. The general network that is widely used today has been integrated in many technological tools from \\
computers to mobile phones and a wide variety of information can be accessed. The content mentions about the points \\
to take into consideration while making search in the general network. The students are well instructed about \\
accessing correct and reliable information and analyzing and evaluating such information. In the following sections of \\
the subject, qualifications of a good media literacy are given in items. Besides the characteristics of being a conscious \\
media literate, the subject is supported with appropriate visuals mentioning about the situations that unconscious users \\
may face (accessing illegal, violent sites and contacting with dangerous people) while using the general network. \\
Mentioning the general network, virtual media, 3D, http//https, e-shopping, cybercrime, identity theft and media \\
literacy, the content is important as it increases general knowledge levels of students.
\end{tabular}

Table 8. Contents on Digital Literacy in the 6th Grade Social Studies Course Book

\begin{tabular}{llll}
\hline Learning Domain & Unit & Grade & Subject \\
\hline- & - & - & - \\
\hline
\end{tabular}

According to Table 8, there is no content regarding technology literacy in the 6th grade social studies course book (Anadol Publishing).

Table 9. Contents on Media Literacy in the 6th Grade Social Studies Course Book

\begin{tabular}{llll}
\hline Learning Domain & Unit & Grade & Subject \\
\hline- & - & - & -
\end{tabular}

According to Table 9, there is no content regarding media literacy in the 6th grade social studies course book (Anadol Publishing).

Table 10. Contents on Digital Literacy in the 7th Grade Social Studies Course Book

\begin{tabular}{llll}
\hline Learning Domain & Unit & Grade & Subject \\
\hline Production, Distribution and Consumption & Economy and Social Life & 7 & Digital World \\
\hline
\end{tabular}

According to Table 10, the 7th grade social studies course book (Ekoyay Publishing) states that scientific and technological developments affect production, distribution and consumption network as in every aspect of life in the subject of "Digital World" in the "Production, Distribution and Consumption, Economy and Social Life" unit. It is mentioned that production types have changed thanks to digital technologies, distribution is made over the general 
network and face-to-face trade takes place in virtual media in general. The subject also mentions that with connection of mobile phones to the general network, mobile phones are not only used to make calls but also to text, make video calls and share videos. The subject is provided to students being supported with appropriate visuals to draw their attention. At the end of the subject, there is an activity about shopping on the general network.

Table 11. Contents on Media Literacy in the 7th Grade Social Studies Course Book

\begin{tabular}{llcl}
\hline Learning Domain & Unit & Grade & Subject \\
\hline Individual and Society & Communication and Human Relations & 7 & The Place of Media in Our Life \\
\hline
\end{tabular}

According to Table 11, there is content in the 7th grade social studies course book (Ekoyay Publishing) allowing students to make inferences about the role of media in social change and interaction in the subject of "The Place of Media in Our Life" in the "Individual and Society, Communication and Human Relations" unit. The content includes social media concept and online concepts in connection with media concept. The reasons why people use the general network are listed. In the following section, aspects of social media that facilitate human life are provided with examples. Furthermore, the problems arising from misuse of social media (information pollution, waste of time, language destruction and terminating interpersonal communication) are included.

\section{Discussion, Conclusion and Recommendations}

Social studies course whose main objective is to bring up efficient and responsible citizens is one of the courses that is important for individuals to have international mindedness. Today, it has become necessary to adapt to the situation with the technological transformation changing the society too. It is inevitable that education be affected by the technology as in other areas of social studies (Karaduman and Öncül, 2019). This change reflects into the curricula of courses and therefore into course books. Accordingly, education programs are updated occasionally. This update shows its effect on all components of education programs. This study investigated the extent to which digital literacy and media literacy among important literacy types in our day are included in the social studies course books of the 4th, 5th, 6th and 7th grades that was updated in 2018. The study found that the social studies curriculum includes digital literacy and media literacy as concepts and digital competence reflects into the basic approach of the social studies curriculum. It is seen that many types of literacy were included in the targeted learning outcomes for students in the 2018 curriculum and digital literacy and media literacy skills were included. The content about digital literacy skills in the social studies course books were found to be in the 5th grade. There is no content that can be associated with digital literacy in the social studies course book of the 4th and 6th grades. In particular, considering that children spend nearly 900 hours at school and 1500 hours watching television annually, digital literacy and media literacy should have a wider coverage in the course books (Çakır, 2013). The technology and media developed in the 21st century have become attractive to everyone with extraordinary techniques and channels they use. Children especially take any material they are offered as it is among the imposed information mass (Bakan, 2010). When the relationship developed by children through digital tools are used consciously, they can be affected by it positively (Gençer, 2018). Considering that digital technology which penetrates into the whole world spreads today, the contents about digital literacy should be included in the social studies course books of all levels in an increasing way. This study found that digital literacy skills are included in two out of seven learning domains (Science, Technology and Society, and Production, Distribution and Consumption) in the social studies curriculum and four learning outcomes are related to digital literacy. The learning outcomes related to digital literacy were Science, Technology and Society learning domain mostly. Altun (2010), associated the high number of learning outcomes regarding digital literacy skills in the social studies curriculum with the existence of "Science, Technology and Society" learning domain. Berber (2019), determined that all of the digital literacy themes in the 5th grade social studies course book prepared for the 2018-2019 academic year were included in the "Science, Technology and Society" learning domains. The research results from the literature support this study. This study found that the number of learning outcomes in the digital literacy skills (4 outcomes) in the social studies curriculum is more than media literacy skills ( 3 outcomes).

Digital literacy is included in only one subject in the 5th and 7th grades social studies course books. In consideration of the content related to digital literacy in social studies textbooks, contents are prepared so that students understand the impact of technology use on socialization and social relations in accordance with the basic approach of the curriculum, question the information they obtain from virtual media, know the security rules while using the virtual media and increase their awareness about it, and analyze the changes in social relations and culture caused by digital technologies in the production, distribution and consumption network. Another focal point of this study is media literacy. Media literacy which is included in the social studies curriculum as a skill and taught as an elective course has taken its place among the popular literacy skills of today. This study found three learning outcomes in the social 
studies curriculum to be related with media literacy. Media literacy is included in three learning domains (Science, Technology and Society, Global Connections, and Individual and Society). Berber (2019), determined that all of the media literacy themes in the 6th grade social studies course book prepared for the 2018-2019 academic year were included in the "Global Connections" learning domain.

It has become an obligation to acquire new communication skills to maximum benefit from the opportunities offered by developing technology today and to minimize its negative effects. Thus, media literacy comes to the fore as communication skills that should be acquired by individuals from childhood (Bozkurt, 2012). The contents about media literacy in social studies course books examined in this study were oriented to students question the accuracy and reliability of the information accessed in a virtual environment, understand negative effects of popular culture and media on the culture, and make inferences about the role of media on social change and interaction. As technology grows stronger in the 21st century and mass communication tools become dominant in the society, it has become more and more important to teach students the skills to critically analyze any text they encounter. Therefore, there is a need for media literacy in teaching social studies just as media literacy education needs social studies (NCSS, 2007; Altun, 2010).

This study found that social studies curriculum covers less learning outcomes about media literacy and contents in the social studies course book. This may stem from the fact that media literacy is offered as an elective course in the secondary schools. However, it should be noted that not all students will choose this course since media literacy is an elective course in these schools. It may be more accurate to teach media literacy from preschool to university level being associated with the present programs (Altun, 2010). In this consideration, including more contents about both digital literacy and media literacy in social studies course books may increase students' competence in this field.

\section{Recommendations}

Some suggestions based on the conclusions from this study are as follows: The number of contents about digital literacy and media literacy can be increased in the social studies course books to be published. The number of learning outcomes regarding these two literacy types can be increased in the curriculum. Finally, the number of activities can be increased in the course books regarding digital literacy and media literacy.

\section{References}

Aksu, Y. (2019). Studying attitudes of student and opinions of teacher and teacher candidate regarding the media literacy lesson, Master Thesis. Institute of Social Sciences, Giresun University, Giresun.

Alımc1, F. (2019). A research on internet media literacy awareness of parents in Kayseri, Master Thesis. Institute of Social Sciences, Erciyes University, Kayseri.

Altıner, S. (2019). Developing digital literacies of pre-service efl teachers through engagement with research, Doktoral Thesis, Institute of Educational Sciences, Bahçeşehir University, İstanbul.

Altun, A. (2010). Teaching of media literacy and its integration into social studies curricula, Doctoral Thesis, Institute of Educational Sciences, Gazi University, Ankara.

Altun, N. (2019). Investigation of primary education curricula and textbooks in the context of digital literacy, Unpublished Master Thesis, Institute of Educational Sciences, Gazi University, Ankara.

Arslan, S. (2019). Investigation of digital literacy levels of teachers working in primary and secondary schools in terms of various variables, Unpublished Master Thesis, Institute of Educational Sciences, Sakarya University, Sakarya.

Bakan, U. (2010). The evaluation of the effect of critical thinking skills over primary education media literacy courses, Master Thesis. Institute of Social Sciences, Atatürk University, Erzurum.

Benek, İ. (2019). Examination of the effect of socioscientific stem's activities on students' attitudes and 21st century skills. Master Thesis. Institute of Graduate Education, İstanbul University, İstanbul.

Berber, H. M. (2019). Investigation of middle school social studies textbooks in terms of literacy skills, Master Thesis, Institute of Education Sciences, Anadolu University, Eskişehir.

Berg, B. L., \& Lune, H. (2015). Qualitative research methods in the social sciences H. Aydın (Tr. Edt). Konya: Eğitim Publishing.

Binark, M., \& Bek, M. (2007). Critical Media Literacy Theoretical Approaches and Applications. İstanbul: Kalkedon Publishing. 
Boyac1, Z. (2019). The relationship between lifelong learning tendencies and digital literacy levels of pre-service teachers (A Düzce University sample), Unpublished Master Thesis, Institute of Educational Sciences, Sakarya University, Sakarya.

Bozkurt, İ. (2012). Students course field view of media literacy for the media: Example Kayseri, Master Thesis, Institute of Social Science, Selçuk University, Konya.

Bozyel, M. (2019). Investigation of teacher candidates' digital literacy course experiences in terms of daily life, Unpublished Master Thesis, Institute of Educational Sciences, Atatürk University, Erzurum.

Buckingham, D. (2010). Defining Digital Literacy. What Young People Need to Know About Digital Media. B. Bachmair, Medienbildung in Neuen Kulturräumen, (s. 59-71). Verlag: Sozialwissenschaften. https://doi.org/10.1007/978-3-531-92133-4_4

Carmen, L. (1999). Media and Cultural Studies in Australia, Journal of Adolescent and Adult Literacy, 42(8), 622-626.

Cebeci, Ü. (2020). An investigation of pre-service efl teachers' digitalliteracy skills and the integration of these skills intoteaching contexts with a special focus to the use of digitaltools and their benefits, Unpublished Master Thesis, Institute of Social Sciences, Karadeniz Teknik University, Trabzon.

Çakır, H. (2013). Determining the differences in media watching behaviors of primary school students who took and did not take the media literacy course, Selçuk İletişim, 7(3), 42-54. Retrieved from https://dergipark.org.tr/tr/pub/josc/issue/19025/200560

Dayanıklı, F. (2019). Relationship between healthy lifestyle, health literacy and digital literacy among the nursing students, Unpublished Master Thesis, Institute of Health Sciences, Düzce University, Düzce.

Dolanbay, H. (2018). Media literacy education model for social studies pre-service teachers, Unpublished Doctoral Thesis, Institute of Educational Sciences, Marmara University, İstanbul.

Eshet-Alkalai, Y. (2004). Digital Literacy: A Conceptual Framework for Survival Skills in The Digital Era. Journal of Educational Multimedia and Hypermedia, 139(1), 93-106. Retrieved From: https://www.openu.ac.il/personal_sites/download/Digitalliteracy2004-JEMH.pdf.

Europe's Information Society. (2007). Media literacy: Do people really understand how to make the most of blogs, search ongines interactive TV? Retrieved from: http://europa.eu/rapid/pressReleasesAction.do?reference=IP/07/1970andformat=H61Landaged=0andlanguage $=\mathrm{E}$ NandguiLanguage.

Exposure and Toddler Development. Arch Pediatr Adolesc, 164(12), 1105-1111. https://doi.org/10.1001/archpediatrics.2010.235

Gençer, R. (2018). Investigation of the results of the study on the current situation in the context of media and child relations, Master Thesis, Institute of Education Sciences, Sakarya University, Sakarya.

Gilster, P. (1997). Digital Literacy, New York: John Wiley.

Gülmüş, İ. (2020). Investigation of primary students' parents media literacy levels, Master Thesis. Institute of Education Sciences, Ege University, İzmir.

Gürtekin, A. (2019). Examining university students' leisure attitudes and socialization tactics and digital literacy levels, Unpublished Master Thesis, Institute of Social Sciences, Ağrı İbrahim Çeçen University, Ağrı

Hague, C., \& Payton, S. (2010). Digital literacy across the curriculum. Bristol, Retrieved from: http://www.nfer.ac.uk/publications/FUTL06/FUTL06.pdf.

Hamutoğlu, N. B., Güngören, Ö. C., Uyanık, G. K., \& Erdoğan, D. G. (2017). Digital Literacy Scale: adaptation study to Turkish. Ege Journal of Education, 18(1), 408-429. https://doi.org/10.12984/egeefd.329432

İnal, K. (2009). Media literacy handbook. Ankara: Ütopya.

Kalkınma Bakanlığı. (2013). Tenth development Plan (2014-2018). Retrieved from: http://www.kalkinma.gov.tr/Lists/Kalknma\%20Planlar/Attachments/12/Onuncu\%20Kalk\%C4\%Blnma\%20Plan $\% \mathrm{C} 4 \% \mathrm{~B} 1 . \mathrm{pdf}$.

Kara, S. (2021). Examination of the relationship between digital literacy levels of teacher candidates and information search and interpretation strategies in the web environment, Unpublished Master Thesis, Institute of Educational Sciences, Necmettin Erbakan University, Konya. 
Karaduman, H., \& Öncül, B. (2019). Digital citizenship and digital citizenship education C. Öztürk, Z. İbrahimoğlu ve G. Y1ldırım (Ed.), In the light of theoretical foundations and current debates, in the 21st century citizenship and citizenship education (s. 123- 142). Ankara: Pegem Akademi Publishing.

Korkmaz, M. (2020). Determining digital literacy levels of primary school teachers, Unpublished Master Thesis, Institute of Educational Sciences, Eskişehir Osman Gazi University, Eskişehir.

Kozan, M. (2018). Examination of department of computer education and instructional technology teacher candidates' digital literacy levels and cyberbullying sensitivities, Unpublished Master Thesis, Institute of Educational Sciences, Firat University, Elazı $\breve{g}$.

Kurtulmuş, T. (2014). Media literacy in social studies education courses to students of secondary effects, Master Thesis, Erciyes University, Institute of Education Sciences, Kayseri.

Martin, A. (2006). Literacies for the digital age. Martin, A. ve Madigan, E. (Ed.), Digital literacies for learning (3-24). London: Facet. https://doi.org/10.29085/9781856049870.003

Merriam, S. B. (2009). Qualitative research. A guide to design and implementation. San Francisco: John Wiley-Sons.

NCSS. (2007). Strategies for Integrating Media Literacy into the Social Studies Curriculum. Retrieved from: http://www.mediaed.org/studyguides/StrategiesForIntegratingMediaLiteracy/html.

Özoğlu, C. (2019). Analysis of the relationship between the lifelong learning tendencies and digital literacy of teacher candidates (Anadolu University education faculty sample), Unpublished Master Thesis, Institute of Educational Sciences, Anadolu University, Eskişehir.

Partnership for 21st Century Learning. (2015). P21 Framework Definitions. Retrieved from: http://www.p21.org/storage/documents/docs/P21_Framework_Definitions_New_Logo_2015.pdf.

Pedró, F. (2006). The New Millennium Learners: Challenging Our Views on ICT and Learning. Inter-American Development Bank.

Potter J. (1998). Media Literacy. USA: Sage Publications.

Som, S., \& Kurt, A. A. (2012). Media Literacy Levels of Computer Education and Instructional Technology Students, Anadolu Journal of Educational Sciences International, 2(1), 104-119.

Suto, I. (2013). 21st Century Skills: Ancient, Ubiquitous, Enigmatic? A Cambridge. Assessment Publication, 1-28.

Tomopoulos, S., Dreyer, P. B., Berkule, S., Fierman, A. H., Brockmeyer, C., and Mendelsohn, A. H. (2010). Infant Media Exposure and Toddler Development. Arch Pediatr Adolesc, 164(12), 1105-1111. https://doi.org/10.1001/archpediatrics.2010.235

Treske, G. (2011). Why Media Literacy is Necessary? in Media Literacy, (Nurçay Türkoğlu and Melda Cinman Şimşek Eds.), 25-37. İstanbul: Parşomen Publishing.

Ulusoy, A. (2018). Digital Media Literacy and Requirements, A Study On Innovative Practices, Unpublished Mater Thesis, Institute of Social Sciences, Erciyes University, Kayseri.

Wach, E. (2013). Learning about qualitative document analysis. Retrieved from: https://opendocs.ids.ac.uk/opendocs/bitstream/handle/20.500.12413/2989/PP\%20InBrief\%2013\%20QDA\%20FI NAL2.pdf?sequence $=4$.

Yaman, C. (2019). Examination of digital literacy levels of social studies teacher candidates (the example of Niğde Ömer Halisdemir University), Unpublished Master Thesis, Institute of Educational Sciences, Niğde University, Niğde.

Yaşar, Ç. (2019). An investigation of the effect of social media platforms on ict teacher candidate's career trends \& instructional activities, Unpublished Master Thesis, Institute of Sciences, Balıkesir University, Balıkesir.

Yıldırım, A., \& Şimşek, H. (2016). Qualitative research methods in the social sciences. Ankara: Seçkin Publishing.

\section{Copyrights}

Copyright for this article is retained by the author(s), with first publication rights granted to the journal.

This is an open-access article distributed under the terms and conditions of the Creative Commons Attribution license (http://creativecommons.org/licenses/by/4.0/). 